\title{
PELATIHAN PENYUSUNAN RPP TEMATIK BAGI GURU SEKOLAH DASAR DI KECAMATAN SIAK HULU KABUPATEN KAMPAR
}

\author{
Dea Mustika $^{1^{*}}$, Elpri Darta Putra ${ }^{2}$, Dyara Atmy Febriyanti ${ }^{3}$ \\ ${ }_{1,2,3}$ Prodi PGSD, FKIP, Universitas Islam Riau, Indonesia \\ deamustika@edu.uir.ac.id
}

\begin{abstract}
ABSTRAK
Abstrak: Pengabdian kepada masyarakat ini bertujuan untuk membantu guru sekolah dasar dalam merancang dan menyusun RPP tematik. Kegiatan pengabdian dilakukan di kecamatan siak hulu kabupaten Kampar, Riau. Pendekatan yang digunakan adalah pendekatan individu dan pendekatan klasikal. Pendekatan individu dilakukan dengan mengadakan workshop berupa penyampaian materi, sedangkan pendekatan klasikal dilakukan dengan membimbing peserta menyusun RPP tematik. Hasil dari pengabdian ini adalah guru-guru sekolah dasar yang menjadi peserta pengabdian dapat memahami penyusunan RPP tematik sesuai dengan panduan yang telah ada. Selain itu, dengan adanya pengabdian ini dapat memberi konsep pengetahuan baru bagi peserta agar dapat melaksanakan pembelajaran yang lebih baik di kelas-kelas sekolah dasar.
\end{abstract}

Kata Kunci: Pengabdian kepada masyarakat, RPP Tematik, Sekolah Dasar

\begin{abstract}
This community service aims to help primary school teachers in designing and compiling thematic lesson plans. Service activities carried out in the Siak Hulu subdistrict, Kampar district, Riau. The approach used is an individual approach and a classical approach. The individual approach is carried out by holding a workshop and the classical approach is carried out by guiding participants to develop a thematic lesson plan. The results of this service are participants can understand the preparation of thematic lesson plans in accordance with existing guidelines. In addition, with this community service can provide new knowledge concepts for participants to be able to carry out better learning in primary school classes.
\end{abstract}

Keywords: Community Service, Thematic Lesson Plan, Primary School

\section{A. LATAR BELAKANG}

RPP atau rencana pelaksanaan pembelajaran merupakan gambaran prosedur yang dikembangkan oleh guru untuk mencapai kompetensi dasar yang telah ditetapkan dalam standar isi (Nursina, 2016). RPP tematik berbeda dengan RPP biasa, perbedaan utamanya terletak pada tema yang digunakan (Prastowo, 2017). Jika pada RPP biasa pembelajaran dipisahkan sesuai dengan mata pelajaran, pada RPP tematik beberapa mata pelajaran akan dipadukan dalam satu tema. RPP tematik biasanya digunakan untuk pembelajaran di kelas rendah, akan tetapi juga tidak tertutup kemungkinan dapat digunakan pada kelas tinggi (Karli, 2016). Misalnya jika pada sekolah yang menggunakan KTSP 2006 pembelajaran tematik dilakukan hanya pada kelas satu hingga kelas tiga, maka sekolah dengan 
kurikulum 2013 pembelajaran tematik dilaksanakan dari kelas satu hingga kelas enam.

Pentingnya penyusunan RPP tematik di sekolah dasar dapat dilihat dari kemampuan pemahaman dan perkembangan usia siswa (Prastowo, 2017). Siswa sekolah dasar dengan rentang usia 7 - 12 tahun berada tahap perkembangan berpikir operasional konkrit, implikasi dari tahap perkembangan ini adalah siswa masih memandang sesuatu secara holistik (keseluruhan), sehingga siswa akan lebih mudah memahami sesuatu apabila dibelajarkan melalui benda-benda konkrit dan bergantung pada pengalaman yang dialaminya (Syaharuddin, 2018). Apabila pembelajaran dilakukan secara terpisah untuk setiap mata pelajaran, nantinya dapat berdampak pada kurang berkembangnya cara berpikir holistik pada siswa (Zuriah, Sunaryo, \& Yusuf, 2016).

Pengembangan RPP mengacu pada Undang-undang No 19 Tahun 2005 tentang Standar Nasional Pendidikan, yang mana dijelaskan bahwa dalam RPP sekurang-kurangnya memuat tujuan pembelajaran, materi pembelajaran, metode pembelajaran, sumber belajar dan penilaian hasil belajar (Susanah, Ismail, \& Prawoto, 2016). Perbedaan antara pengembangan RPP mata pelajaran dengan RPP tematik tampak pada tema pemersatu yang digunakan. Jika pada RPP mata pelajaran, pembelajaran didasarkan kepada mata pelajaran tertentu maka pada RPP tematik didasarkan pada tema atau subtema yang berfungsi mengikat beberapa mata pelajaran.

Pembelajaran tematik dengan menggunakan RPP tematik awalnya sudah mulai diterapkan di sekolah dasar sejak berlakunya kurikulum 2004, namun penerapannya masih belum sesuai dengan harapan. Pemahaman guru yang beragam tentang penyusunan RPP tematik menjadi penyebab munculnya masalah ini. Walaupun pemerintah telah melakukan berbagai upaya seperti penataran guru, seminar, KKG, lokakarya, bahkan program sertifikasi guru namun masih banyak guru yang belum melaksanakan pembelajaran tematik di sekolah dasar (Suadnyana, Wiyasa, Ardana, Putra, \& Wulandari, 2017). Pembelajaran di sekolah dasar masih didominasi dengan pembelajaran yang fokus pada satu mata pelajaran seperti matematika, IPA, IPS dan lainnya.

Analisis di lapangan, menemukan bahwa sebagian besar guru-guru sekolah dasar belum terlalu memahami pembelajaran tematik dengan baik. Sehingga sebagian besar guru lebih memilih melaksakanan kegiatan pembelajaran dengan sistem pembelajaran biasa. Tidak hanya itu, kurangnya pemahaman guru pada pembelajaran tematik juga berdampak pada ketidakmampuan guru dalam menyusun RPP tematik. Rumusan masalah dalam kegiatan pengabdian ini secara umum adalah bagaimana meningkatkan pemahaman guru terhadap penyusunan RPP tematik di sekolah dasar?. Kegiatan pengabdian ini dimaksudkan untuk meningkatkan pengetahuan dan pemahaman guru akan penyusunan RPP 
tematik, serta membantu guru memahami bentuk pelaksanaan pembelajaran tematik di sekolah dasar.

\section{B. METODE PELAKSANAAN}

Kegiatan pengabdian kepada masyarakat dilaksanakan di SD Negeri 24 Kecamatan Siak Hulu Kabupaten Kampar. Waktu kegiatan dimulai pada bulan Oktober 2018 sampai dengan Desember 2018. Kegiatan pengabdian dilakukan dengan dua pendekatan yaitu pendekatan klasikal dan pendekatan individu. pendekatan klasikal dilakukan dengan cara penyampaian hal-hal teoritis dalam bentuk kegiatan workshop, sedangkan pendekatan individual dilakukan dengan kegiatan pendampingan membimbing guru dalam menyusun RPP tematik. Langkah-langkah kegiatan yang dilakukan adalah :

1. Penjelasan konseptual dari pembelajaran tematik.

2. Penjelasan konseptual tentang alur dan prosedur penyusunan RPP tematik berdasarkan ketentuan yang telah ada.

3. Praktik penyusunan RPP tematik menggunakan panduan yang telah disusun.

4. Pendampingan yang dilakukan oleh dosen kepada guru-guru dalam upaya melakukan kegiatan penyusunan RPP tematik.

5. Pelaksanaan penilaian terhadap RPP tematik yang telah dibuat untuk mengetahui pemahaman guru dalam merancang dan menyusun RPP tematik setelah diberikan pelatihan.

\section{HASIL DAN PEMBAHASAN}

Kegiatan dilaksanakan di ruangan kelas VI SD Negeri 24 Kecamatan Siak Hulu Kabupaten Kampar. Kegiatan pelatihan dilaksanakan diluar jam efektif belajar. Berikut diuraikan tahapan pelaksanaan kegiatan pengabdian pada masyarakat yang dilakukan.

\section{Tahap Persiapan}

Tahap persiapan diawali dengan mempersiapkan segala keperluan alat dan penunjang pelatihan serta melengkapi materi-materi pelatihan yang akan disampaikan pada guru-guru SD.

\section{Tahap Pelaksanaan}

Berikut adalah gambaran kegiatan yang dilakukan pada tahap pelaksanaan. 

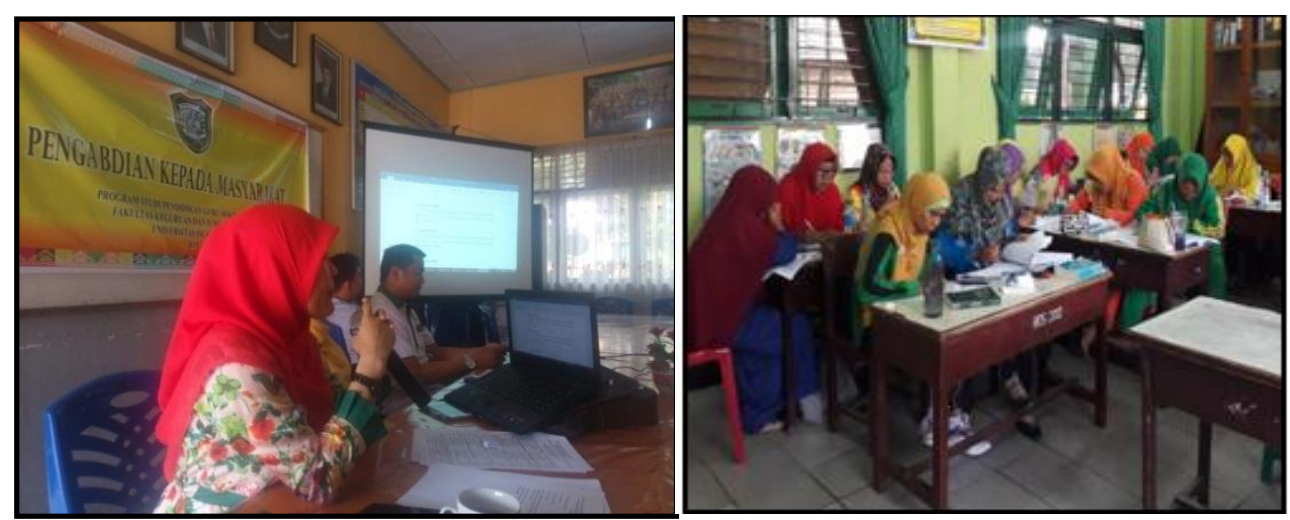

Gambar 1. Penyampaian Materi dan Pelatihan Pembuatan RPP Tematik

Pada gambar pertama dapat adalah kegiatan penyampaian materi kepada peserta pelatihan. Materi yang disampaikan berkenaan dengan tahapan pembuatan RPP tematik, menjelaskan komponen yang harus ada dalam RPP tematik, memberikan panduan perancangan RPP tematik, mencontohkan bentuk rancangan RPP tematik dan membuka sesi tanya jawab. Sedangkan pada gambar kedua dilaksanakan dengan memberikan kesempatan pada guru-guru peserta latihan untuk membuat rancangan pembelajaran tematik sesuai dengan format yang telah dibagikan. Kegiatan menyusun RPP tematik ini dilakukan oleh peserta secara individual sesuai dengan kelas yang diajar.

\section{Tahap Evaluasi}

Tahap ini dilaksanakan dengan kegiatan evaluasi hasil dari kerja yang telah dilakukan oleh peserta pelatihan. Tim pengabdian dibagi untuk membantu menganalisis hasil dari RPP tematik yang telah disusun peserta. Hasil analisis kemudian didiskusikan kembali dengan peserta pengabdian agar peserta dapat mengetahui kekurangan yang terdapat dalam RPP tematik yang telah dirancang.

Observasi awal yang dilakukan oleh tim pelatihan menemukan beberapa permasalahan yang terjadi sehingga guru-guru mengalami kesulitan dalam merancang RPP tematik. Permasalahan tersebut diantaranya kurangnya informasi yang didapatkan guru terkait dengan cara merancang RPP tematik, tidak adanya contoh dari RPP tematik yang sudah baik dan tepat untuk digunakan, serta masih kurangnya kemampuan guru dalam memadukan mata pelajaran menjadi pembelajaran tematik.

Produk dari pelatihan ini adalah peserta pelatihan dapat membuat rancangan RPP tematik yang baik dan sesuai dengan format yang sudah ada. Dari pelaksanaan kegiatan pelatihan didapatkan bahwa pelatihan ini memang perlu dilaksanakan sebagai satu upaya untuk memotivasi guruguru SD memadukan mata pelajaran menjadi pembelajaran tematik, agar pembelajaran yang dilaksanakan memang sesuai dengan kondisi dan kebutuhan siswa SD itu sendiri. Selain itu, pengetahuan guru dalam 
merancang RPP tematik nantinya juga dapat dimanfaatkan guru untuk mengembangkan kemampuan dalam melaksanakan Penelitian Tindakan Kelas (PTK).

Dilihat dari antusias peserta pelatihan, kegiatan ini perlu dilakukan secara berkesinambungan agar dapat memberikan pemahaman yang lebih baik pada guru-guru yang menjadi peserta pelatihan pembuatan RPP tematik. Kegiatan pelatihan ini memberi pemahaman pada guru tentang RPP tematik, dan juga memberi pemahaman dalam memadukan mata pelajaran sehingga dapat diaplikasikan dalam bentuk kegiatan belajar mengajar. Hal lain yang juga didapatkan peserta melalui kegiatan pelatihan ini adalah memahami cara merumuskan sub tema, merumuskan indikator dan tujuan pembelajaran yang baik, dan menentukan metode pembelajaran yang sesuai.

\section{SIMPULAN DAN SARAN}

Kegiatan pengabdian pada masyarakat difokuskan pada perancangan RPP tematik pada guru-guru sekolah dasar. Kegiatan dilaksanakan sesuai dengan perencanaan dan telah mencapai sasaran yang diharapkan. Kegiatan pengabdian ini dapat memberi pemahaman pada guru-guru sekolah dasar bagaimana merancang RPP tematik yang baik serta dapat membuat sendiri RPP tematik dengan format yang telah dibagikan. Hal lain yang juga menjadi nilai tambah dari kegiatan pelatihan yang diberikan adalah para peserta pelatihan dapat mengembangkan kemampuan merancang RPP tematik untuk melaksanakan Penelitian Tindakan Kelas.

Beberapa saran yang dapat diberikan dari hasil kegiatan pengabdian yang telah dilakukan adalah sebagai berikut.

1. Pelatihan dan pendampingan sebaiknya dilakukan secara berkesinambungan dan tidak hanya berhenti di satu waktu tertentu saja.

2. Diperlukan adanya interaksi yang lebih dekat lagi dengan peserta pelatihan agar peserta lebih memahami cara memadukan atau merangkai kegiatan pembelajaran yang baik dalam merancang RPP tematik.

\section{UCAPAN TERIMA KASIH}

Tim penulis mengucapkan terima kasih kepada Lembaga Pengabdian Pada Masyarakat (LPPM) Universitas Islam Riau yang telah mendukung dan mendanai kegiatan pengabdian ini sehingga terlaksana dengan baik. Selain itu, tim penulis juga mengucapkan terimakasih kepada pihak UPTD Dinas Pendidikan Kecamatan Siak Hulu yang telah memberikan izin untuk mengadakan kegiatan pelatihan bagi guru-guru sekolah dasar di kecamatan siak hulu,kabupaten Kampar, Riau. Ucapan terimakasih tak 
lupa juga penulis sampaikan kepada pihak-pihak lain yang telah banyak membantu sehingga kegiatan pengabdian ini dapat terlaksana dengan baik.

\section{DAFTAR RUJUKAN}

Karli, H. (2016). Penerapan Pembelajaran Tematik SD Di Indonesia. EduHumaniora / Jurnal Pendidikan Dasar Kampus Cibiru, 2(1). https://doi.org/10.17509/eh.v2i1.2752

Nursina, N. (2016). Peningkatan Kompetensi Pedagogik Guru SDN 38 Sungai Limau dalam Menyusun RPP Melalui Workshop Penyusunan RPP pada Kegiatan KKG Mini SDN 38 Sungai Limau Kabupaten Padang Pariaman. Jurnal Konseling Dan Pendidikan, 4(2), 79. https://doi.org/10.29210/16700

Prastowo, A. (2017). Menyusun Rencana Pelaksanaan Pembelajaran (RPP) Tematik Terpadu. In Kencana.

Suadnyana, I. N., Wiyasa, I. K. N., Ardana, I. K., Putra, D. K. N. S., \& Wulandari, I. G. A. A. (2017). Pelatihan Penyusunan RPP Tematik Integratif Menggunakan Pendekatan Saintifik Bagi Guru-Guru Sekolah Dasar Gugus Viii Abiansemal Badung Tahun Pelajaran 2015/2016. International Journal of Community Service Learning, 1(1), 63. https://doi.org/10.23887/ijcsl.v1i1.11908

Susanah, S., Ismail, I., \& Prawoto, B. P. (2016). Pelatihan Penyusunan Rencana Pelaksanaan Pembelajaran Berdasarkan Kurikulum 2013 Di SD Negeri 3 Sidokumpul Gresik Kabupaten Gresik. Jurnal ABDI, 1(1), 67. https://doi.org/10.26740/ja.v1n1.p6770

Syaharuddin, V. M. (2018). Meningkatkan Kemampuan Berhitung Siswa Sd Menggunakan Metode Jarimatika. JCES, 1(1), 30-33.

Zuriah, N., Sunaryo, H., \& Yusuf, N. (2016). IbM Guru Dalam Pengembangan Bahan Ajar Kreatif Inovatif Berbasis Potensi Lokal. Jurnal Dedikasi, 8(0), 39-49. 